\title{
Milka Bliznakov, 1927-2010
}

Milka Tcherneva Bliznakov, a gracious pioneering figure who remains a powerful inspiration for all women in architecture across the globe, passed away in her home in Blacksburg, Virginia, on 4 November 2010. A prominent educator, scholar, and architect and professor emerita of architecture in the College of Architecture and Urban Studies at Virginia Polytechnic Institute and State University, Bliznakov established a remarkable legacy. Aiming to document the history of women's contributions to the built environment, she founded and chaired the now world-renowned International Archive of Women in Architecture (IAWA) that continues to collect and archive the professional papers of women architects, urban planners, landscape architects, designers, architectural historians and critics, as well as the records of women's architectural organizations. Bliznakov was passionate about the role of professional women in architecture. In a time of global transitions, not only was she the face of IAWA for many international colleagues, she was the soul of sisterhood, international support, and recognition.

Born in Varna, Bulgaria, on 20 September 1927, Bliznakov received her master's degree in architecture from the State Polytechnic University of Sofia in 1951 and the following year began practicing architecture in Bulgaria, the eastern block country that was considered a "younger sister" of the Soviet Union. Due to political circumstances, she moved her professional practice to France in 1959, and in 1961 she immigrated with her family to the United States, where she worked as an architect until 1972. Here she interwove the textures of her professional and personal experiences with investigations into the history of early Soviet architecture. After completing her studies and receiving the PhD degree in architectural history from Columbia University in 1971, Bliznakov began her academic career at the University of Texas. There, as a member of a group of talented faculty, she was one of the co-founders of the Institute of Modern Russian Culture, now highly acclaimed and active at the University of Southern California, Los Angeles.

In 1974, Bliznakov joined the School of Architecture and Design at Virginia Tech and continued her research and teaching in the advanced design of urban environments until her retirement in 1998. She earned a reputation as one of the most effective and respected scholars of her generation and a recognized authority on Russian constructivism and the avant-garde movement.

Bliznakov was the recipient of several prominent awards, such as the Parthena Medal for Excellence in Architecture from the Bulgarian government in 1985, Fulbright-Hays Fellowships in 1983 and 1991, International Research and Exchange grants in 1984 and 1993, a National Endowment for the Arts grant in 1973, and a grant from the Woodrow Wilson International Center, Smithsonian Institution, in 1988. Her best-known publications include From Theory to Practice in Constructivist Architecture (1979) and History and Theory of Urban Form (1985), and her manuscript, "A Bibliographical Guide to Their Work: Soviet Women Architects, 1917-1937" (1994) offers valuable data for academic research.

With her talent, enthusiasm, dedication, not to mention her open mind and enlightened spirit, Bliznakov supported many of us in our plans and projects. I will never forget my first encounter with her at the annual meeting of the Society of Architectural Historians in Richmond, Virginia. Her sparkling personality attracted everyone, and her warm attitude toward students and faculty was amazing. Women architects from diverse continents collaborated at all levels thanks to Bliznakov's motivation, encouragement, and kind offers to stay at her home for the IAWA Annual Meetings, which she would sometimes call "congresses." She provided pivotal support for my efforts to organize for the IAWA a collection of records concerning remarkable Russian women architects who represent over 50 percent of our professional workforce there yet remain largely unknown in the west. Bliznakov was an profound inspiration for me because our paths crossed in so many ways, and it was thanks to her philosophy and initiative that I was appointed the first honorary advisor to the IAWA Board of Advisors in 2002.

Bliznakov's vivid recollections of her ideologically charged decisions, her remarkable

Slavic Review 70, no. 2 (Summer 2011) 
professional engagements, her doctoral studies at Columbia University, and her teaching and research in Texas and Virginia were shaped by and perceived through the magnifying glass of the contradictions of historical narratives and the inconsistencies and voids in the fabric of life and global transitions pertaining to past and present. She saw and understood the emotional link between our spaces of contrasting projections, similarities of fortune, and imaginary excavations of the plains of memory of living in communal utopias. I cherish the many letters, cards, and packages I received from her, our telephone conversations, and our professional and personal discussions! While teaching at Miami University, I was delighted to help arrange the Milka Bliznakov gift of rare books to Miami University's King Library.

As IAWA board advisor Kristine K. Fallon, FAIA, wrote about Bliznakov, "She was an educator who opened vistas for her students, as she has opened a view into the work and contributions of women in architecture for the international design community. She was personally excited to encounter new knowledge and new experiences and she communicated that inexhaustible intellectual zest to all." Board advisor Helga Schmidt-Thomsen added, "She was a great personality, a strong fighter, had faced so many struggles in her life and really was an exceptional character in her generation. IAWA is a great legacy, and we all will keep Milka in mind thankfully and with a smiling face." The IAWA honors her memory through the annual Milka Bliznakov Prize given to architects, scholars, and researchers for their research on women in architecture and related design fields. This research, in concert with the preservation efforts of the IAWA, helps bridge the gap in historical knowledge about women's professional achievements.

Milka Bliznakov was a strong, beautiful, and generous person, with a graceful sense of humor and a remarkable talent for overcoming hardships and realizing the most challenging aspirations. A gifted and inspiring teacher and an exceptionally caring individual who always championed human rights, she leaves behind a pioneering legacy that will continue to shine brightly for generations to come.

\author{
ANNA Sokolina \\ Executive Editor, Alternative Spaces \\ December 2010
}

\title{
Michael Confino, 1926-2010
}

Michael Confino, one of the greatest historians of eighteenth- and nineteenth-century Russia, came from a Bulgarian Sephardic family then living in Sofia, where he was born on 2 April 1926. As he loved to remember, before the war his family spent long months in France, and he was awarded the gold medal as the best student in Sofia's French lycée by Angelo Roncalli, the apostolic nuncio in the Balkans who was to become Pope John XXIII. Like other Bulgarian Jews, Confino survived the Shoah thanks to the Bulgarians' courageous behavior, and before emigrating to Israel in 1948, he attended the University of Sofia.

After serving the newly born state of Israel in various capacities, Confino studied at Hebrew University (1955-57) and then, by virtue of a French government scholarship, at the Sorbonne and the Sixième section of the École pratique des hautes études (1957-59), the nucleus of Fernand Braudel's École des hautes études.

Confino thus found himself at the very heart of the Annales' historiographic revolution, in which he actively participated, creating his own original place by virtue of his capacity to combine social, economic, and intellectual history. Acutely aware of the importance of comparative history, of the collective psychology of social groups, and of structures, Confino was at the same time attuned to the history of minorities and individuals. This combination was to give his writings that extraordinary capacity to "breathe" and that extremely rich texture that still distinguish them even among the works of other major historians.

A professor at Hebrew University (1959-70), whose Department of Russian Studies he founded, Confino rapidly established himself as perhaps the world's leading specialist 